\title{
Leukocytes respiratory burst and lysozyme level in pacu (Piaractus mesopotamicus Holmberg, 1887)
}

\author{
Abreu, JS. ${ }^{\mathrm{a}}$, Marzocchi-Machado, CM. ${ }^{\mathrm{b}}$,Urbaczek, AC. ${ }^{\mathrm{c}}$, Fonseca, LM. ${ }^{\mathrm{c}}$ and Urbinati, EC. ${ }^{\mathrm{d} *}$
}

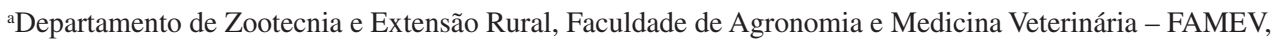
Universidade Federal do Mato Grosso - UFMT,

Av. Fernando Corrêa da Costa, s/n, Coxipó, CEP 78060-900, Cuiabá, MT, Brazil

${ }^{\text {b} D e p a r t a m e n t o ~ d e ~ A n a ́ l i s e s ~ C l i ́ n i c a s, ~ T o x i c o l o ́ g i c a s ~ e ~ B r o m a t o l o ́ g i c a s, ~}$ Faculdade de Ciências Farmacêuticas de Ribeirão Preto, Universidade de São Paulo - USP,

Via do Café, s/n, Monte Alegre, CEP 14040-903, Ribeirão Preto, SP, Brazil

'Departamento de Análises Clínicas, Faculdade de Ciências Farmacêuticas de Araraquara,

Universidade Estadual Paulista Júlio de Mesquita Filho - UNESP,

Rua Expedicionários do Brasil, 1621, Centro, CEP 14801-902, Araraquara, SP, Brazil

${ }^{d}$ Centro de Aqüicultura - CAUNESP, Universidade Estadual Paulista Júlio de Mesquita Filho - UNESP,

Via de Acesso Prof. Paulo Donato Castelane, CEP 14884-900, Jaboticabal, SP, Brazil

Received March 25, 2008 - Accepted May 13, 2008 - Distributed November 30, 2009

*e-mail: bethurb@caunesp.unesp.br

(With 6 figures)

\begin{abstract}
Innate immune responses are useful to determine the health status of fish and to evaluate the effect of immunomodulatory substances in fish farming. Leukocytes respiratory burst was measured in pacu (Piaractus mesopotamicus) using chemiluminescence assay and nitroblue tetrazolium (NBT) reduction assay. The nitroblue tetrazolium reduction seemed more adequate than chemiluminescence assay for leukocytes oxidative burst determination, since it was difficult to isolate the blood leucocytes for chemiluminescence assay. Plasma and serum lysozyme were measured using a turbidimetric assay. The heating of serum and plasma samples $\left(56^{\circ} \mathrm{C}\right.$ for 30 minutes $)$ for complement system inactivation darkened the plasma samples and interfered in the results. The lysozyme activity in serum was higher than in plasma, suggesting that serum samples are more appropriate for the analysis. This study established protocols that can be useful tools in the study of immune mechanisms of the tropical fish pacu.
\end{abstract}

Keywords: pacu, Piaractus mesopotamicus, innate immunity, respiratory burst, lysozyme.

\section{Atividade respiratória de leucócitos e nível de lisozima em pacu (Piaractus mesopotamicus)}

\begin{abstract}
Resumo
Respostas imunológicas inatas são úteis para determinar o estado de saúde de peixes e avaliar o efeito de substâncias imunomoduladoras no cultivo destes animais. A atividade respiratória de leucócitos foi medida em pacu (Piaractus mesopotamicus) através de ensaio de quimioluminescência e ensaio de redução do nitroblue tetrazolium (NBT). O ensaio de redução do nitroblue tetrazolium pareceu mais adequado que o ensaio de quimioluminescência para determinação da atividade respiratória de leucócitos, uma vez que foi difícil isolar com êxito os leucócitos do sangue para o ensaio de quimioluminescência. Lisozima sérica e plasmática foram medidas por meio de ensaio turbidimétrico. Com o objetivo de inativar as proteínas do sistema complemento, as amostras de soro e plasma foram aquecidas $\left(56{ }^{\circ} \mathrm{C}\right.$ por 30 minutos). Porém, este procedimento provocou a turvação das amostras de plasma e interferiu nos resultados. A atividade de lisozima no soro foi maior que no plasma, sugerindo que amostras de soro são mais apropriadas para esta análise. Este estudo estabeleceu protocolos que podem ser utilizados como ferramentas no estudo de mecanismos imunológicos do peixe tropical pacu.
\end{abstract}

Palavras-chave: pacu, Piaractus mesopotamicus, imunidade inata, burst oxidativo, lisozima. 


\section{Introduction}

Immunity is an important defence mechanism to protect the animal body against infection and to maintain homeostasis. Leukocytes, after diapedesis and chemotaxis to the lesion, recognize, phagocyte and degrade pathogens (Roitt et al., 1998). When phagocytosis is initiated, there is a dramatic increase of the molecular oxygen consumption by the phagocytic cells called oxidative burst. The oxygen is converted via the NADPH oxidase system into superoxide anions, hydrogen peroxides, singlet oxygen and hydroxyl radicals which are powerful microbicidal agents (Klein, 1990; Verlhac and Gabaudan, 1997).

In teleost fish, the literature reports methods to determine the reactive oxygen species (ROS) produced during the respiratory burst such as chemiluminescence assay (Verlhac et al., 1996; Verlhac et al., 1998; Cuesta et al., 2002) and reduction of ferricytochrome C (Jorgensen et al., 1993; Jeney et al., 1997; Santarém et al., 1997; Lee et al., 2004). However, the nitroblue tetrazolium (NBT) assay is mostly used to measure the oxidative radical production by leukocytes in the defence against pathogens (Jeney and Anderson, 1993; Jeney et al., 1997; Castro et al., 1999; Cook et al., 2003; Sahoo et al., 2005).

Lysozyme level or activity is an important index of innate immunity of fish. It is well documented that fish lysozyme possess lytic activity against bacteria. It is also known to be opsonic in nature and activates the complement system and phagocytes. Lysozyme splits the $\beta 1,4$, glycosidic linkages between $\mathrm{N}$-acetylmuramic acid and $\mathrm{N}$-acetylglucosamine in the cell walls of Gram-positive bacteria thus preventing them from invading (Paulsen et al., 2003). When the outer cell wall of Gram-negative bacteria is disrupted due to the action of complement and other enzymes exposing the inner peptidoglycan layer of bacteria, then lysozyme becomes effective (Verlhac and Gabaudan, 1997). Lysozyme is measured by a turbidimetric assay based on the lysis of Gram positive bacteria, Micrococcus lysodeikticus, and this methodology is the most used in fish (Sankaran and Gurnani, 1972; Lie et al., 1989; Jorgensen et al., 1993; Verlhac et al., 1996; Jeney et al., 1997; Santarém et al., 1997; Verlhac et al., 1998; Cuesta et al., 2002; Balfry and Iwama, 2004).

The pacu (Piaractus mesopotamicus) is a fish of high commercial value in Brazilian aquaculture and one of the most important farmed fish in the south, southeast and mid-west of Brazil (Urbinati and Gonçalves, 2005). Studies have been carried out on its reproduction and larviculture (Romagosa et al., 1990; Jomori et al., 2003), feeding and nutrition (Bechara et al., 2005; Abimorad et al., 2007) and stress response (Krieger et al., 1989; Takahashi et al., 2006). However, little has been explored about its immune status. Few studies evaluated the effect of vitamin C as immunostimulant (Martins, 1995; 1998) and the immune system responses were measured by counting leukocytes and trombocytes. The objective of the present work was to standardise protocols to measure responses of the innate system of pacu such as leucocyte respiratory burst and lysozyme activity.

\section{Materials and Methods}

\subsection{Chemicals}

All chemicals (Dulbecco's phosphate buffered saline (D-PBS); histopaque ${ }^{\circledR} 1119$; luminol; dimethylsulphoxide (DMSO); phorbol 12-myristate 13-acetate (PMA); nitroblue tetrazolium (NBT); hen egg white lysozyme and Micrococcus lysodeikticus lyophilized) were purchased from Sigma Chemical Company (St. Louis, MO, U.S.A.).

\subsection{Experimental design}

Forty eight pacu $(92.0 \pm 20.2 \mathrm{~g})$, provided by the Aquaculture Centre of the State University of Sao Paulo (CAUNESP), Jaboticabal, SP, Brazil, were adapted to the laboratory conditions during 30 days in six $100 \mathrm{~L}$ tanks (eight fish per tank) with constant water and air flows. Water temperature varied from 28 to $31{ }^{\circ} \mathrm{C}$ during the experiment. Physico-chemical water parameters were measured weekly (dissolved oxygen: $5.7 \pm 1.0 \mathrm{mg} . \mathrm{L}^{-1}$; pH: $8.0 \pm 0.1$; total ammonia: $0.3 \pm 0.1 \mathrm{mg} . \mathrm{L}^{-1}$ ). The fish were fed on commercial diet, twice a day until apparent satiety. The uneaten diet and faecal materials were removed every 48 hours. Fish were starved for 12 hours and anaesthetized with benzocaine ( $66 \mathrm{mg} . \mathrm{L}^{-1}$ water) before blood collection.

\subsection{Leukocytes respiratory burst by chemiluminescense assay}

\subsubsection{Isolation of blood leukocytes}

Twenty-four fish (four fish per tank) were bled by puncture of the caudal vessels into syringes with EDTA and blood was used for leukocytes respiratory burst measurement by chemiluminescence assay. Each blood sample resulted from a pool of two fish $(n=12)$. Leukocytes were isolated from blood samples using a density gradient, following the protocol of Jeney et al. (1997), with modifications. Into $15 \mathrm{~mL}$ conic plastic tubes it was added $3 \mathrm{~mL}$ of total blood diluted in $3 \mathrm{~mL}$ of D-PBS buffer, pH 7.2 (3:3). Three millilitres of histopaque $^{\circledR} 1119$ were carefully layered on the top, resulting to $9 \mathrm{~mL}$ final volume. The samples were centrifuged at $700 \mathrm{~g}$ for 30 minutes at room temperature (about $25^{\circ} \mathrm{C}$ ) and plasma was removed. The isolated leukocytes were gently removed and dispensed into $15 \mathrm{~mL}$ conic plastic tubes. Cells were then washed three times in Hanks Balanced Salt Solution (HBSS, pH 7.2), centrifuged at $200 \mathrm{~g}$ for 10 minutes at room temperature and adjusted to $2 \times 10^{6}$ viable cells $\mathrm{mL}^{-1}$ in the same medium following viability estimation using trypan blue exclusion.

\subsubsection{Respiratory burst activity}

Leukocytes respiratory activity was measured by their oxidative burst using the chemiluminescence as- 
say according to Verlhac et al. (1998), with adaptations and PMA as stimulus. The chemiluminescence response was measured on an automated luminometer (Bio Orbit LKB 1251, Turkey, Finland). Substrate used to assess the chemiluminescence response was luminol. Luminol was stored at $10^{-2} \mathrm{M}$ in DMSO and the working solution was obtained by diluting the stock solution at $1: 1000\left(10^{-5} \mathrm{M}\right)$ in HBSS. Into polystyrene tubes, $10 \mu \mathrm{L}$ luminol solution $10^{-5} \mathrm{M}, 280 \mu \mathrm{L}$ leukocytes suspension $\left(5-6 \times 10^{5}\right.$ cells $)$ and $10 \mu \mathrm{L}$ PMA $10^{-5} \mathrm{M}$ were mixed. The volume was adjusted to $1 \mathrm{~mL}$ with HBSS/gelatin $0.1 \%$ and PMA was the last component added. For each sample, there was a negative control without PMA addition. Subsequently, tubes were put into the luminometer at $22{ }^{\circ} \mathrm{C}$. The course time of chemiluminescence response was followed by counting the rate of photons emitted at constant time interval (10 minutes) and registered in millivolts.

\subsection{Leukocytes respiratory burst by NBT assay}

Six fish (one fish per tank) were bled by puncture of the caudal vessels into syringes with EDTA and heparinized syringes $(n=6)$ and blood was used for leukocyte respiratory burst measurement by NBT assay. The NBT assay followed the protocol of Glasser and Fiederlein (1990), with modifications. Briefly, $100 \mu \mathrm{L}$ of heparinized blood were dispensed in Eppendorf and $100 \mu \mathrm{L}$ of $0.1 \%$ NBT solution and $1 \mu \mathrm{L}$ de PMA $10^{-5} \mathrm{M}$ were added. The mixture was incubated for 20 minutes at room temperature $\left(25^{\circ} \mathrm{C}\right)$. For each sample, there was a negative control without PMA addition. After incubation, blood smears stained with Leishman's stain were prepared to determine percent of cells containing intracellular blue formazan particles (i. e. NBT-positive) using a light microscope $(\times 1,000)$. The same procedure was carried out with blood collected in EDTA. However, considering that calcium ion could interfere in the burst oxidative reactions and that EDTA is a chelating agent, the $0.1 \%$ NBT solution was prepared utilizing a PBS buffer enriched with glucose and $\mathrm{Ca}^{+2}$ and $\mathrm{Mg}^{+2}$ ions.

\subsection{Serum and plasma lysozyme assay}

Twelve fish (two fish per tank) were bled by puncture of the caudal vessels into syringes with EDTA (for plasma) and syringes without an anticoagulant (for serum). Each blood sample resulted from a pool of two fish $(n=6)$. The blood was centrifuged (600 $\mathrm{g}$ for 10 minutes) and serum and plasma were separated and kept at $-20{ }^{\circ} \mathrm{C}$ until lysozyme analysis. The lysozyme level was measured by turbidimetric assay according to Ellis (1990), using hen egg white lysozyme (1 mg/lysozyme. $\left.\mathrm{mL}^{-1}\right)$ as standard with partial modifications. A suspension of Micrococcus lysodeikticus $\left(0.2 \mathrm{mg} . \mathrm{mL}^{-1} 0.05 \mathrm{M}\right.$ sodium phosphate buffer $\mathrm{pH}$ 6.2) was used. Lysozyme working solution ( $1 \eta \mathrm{g} . \mu \mathrm{L}^{-1}$ ) was obtained by diluting the stock solution a hundred times with sodium phosphate buffer $\left(\mathrm{NaH}_{2} \mathrm{PO}_{4}\right.$; $0.05 \mathrm{M}$; pH 6.2) and a calibration curve was developed. Serum and plasma samples were heated (water-bath at $56{ }^{\circ} \mathrm{C}$ for 30 minutes) to inactivate complement system proteins and to certify that lysis of $M$. lysodeikticus had exclusively occurred by lysozyme action. Part of standard lysozyme was also heated to verify its activity with this treatment and two curves (lysozyme heated and not) were developed. Different serum and plasma volumes $(150 ; 175 ; 200 ; 225 ; 250$ and $275 \mu \mathrm{L})$ were dispensed into glass tubes and sodium phosphate buffer was used to complete $300 \mu \mathrm{L}$ final volume. The samples were incubated for 2 minutes in the spectrophotometer (Beckman DU-70S) at $26^{\circ} \mathrm{C}$ and $300 \mu \mathrm{L}$ Micrococcus lysodeikticus suspension $\left(0.2 \mathrm{mg} \cdot \mathrm{mL}^{-1}\right)$ was added to complete $600 \mu \mathrm{L}$ final volume. A blank sample was prepared using sodium phosphate buffer $(600 \mu \mathrm{L})$. Difference between the initial and final turbidity (optical density (OD) reduction) was measured between 0.5 and 10 minutes at $450 \eta \mathrm{m}$. Results were expressed using the values of OD reduction for each sample volume versus sample volume analysed $(\mu \mathrm{L})$. The linear regression equation of lysozyme calibration curve was used to determine the serum and plasma lysozyme levels $\left(\mu \mathrm{g} \cdot \mathrm{mL}^{-1}\right)$.

\subsection{Statistical analysis}

Data were statistically analysed only in NBT assay by SAS software. Means and standard deviation of the mean (S.D.M.) were calculated for each parameter (blood with EDTA or heparin). Differences among the anticoagulant used were assessed by one-way ANOVA. Mean values were compared using Tukey's test using $\mathrm{P}<0.05$.

\section{Results}

\subsection{Chemiluminescence assay}

In this assay, leukocytes were isolated only in a few blood samples, in which the oxidative burst was measured by the chemiluminescence response (Figure 1a, $\mathrm{b}$ and $\mathrm{c})$.

\subsection{NBT assay}

Independent of the anticoagulant, there were NBT positive cells in blood smears without significant difference among them (Figure 2). However, the leukocyte visualisation was more difficult in heparinezed blood (Figure $3 b$ ) than blood collected with EDTA (Figure 3a).

\subsection{Lysozyme assay}

The lysozyme calibration curve presented a high linear correlation $\left(\mathrm{r}^{2}=0.9862\right)$ between 50 and $300 \eta$ g lysozyme. $300 \mu \mathrm{L}^{-1}$ (Figure 4). The serum and plasma lysozyme levels $\left(\mu \mathrm{g} \cdot \mathrm{mL}^{-1}\right)$ are presented in Table 1. The heat did not inactivate lysozyme. However, lysozyme submitted to heat presented lower activity than lysozyme not heated (Figure 5). The highest values of OD reduction were found in serum samples, indicating that serum lysozyme activity was higher than the plasma activity (Figure 6). 

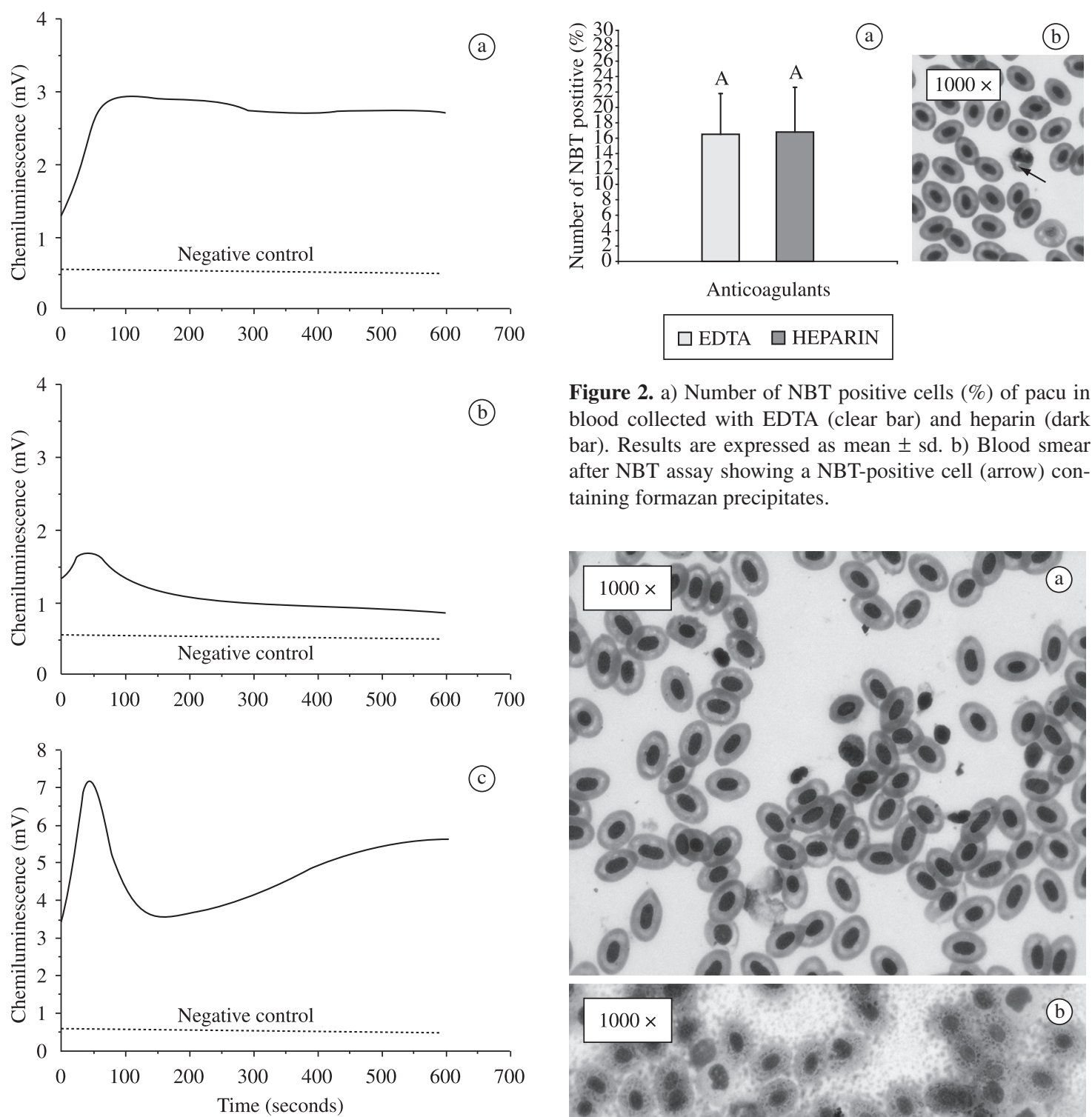

Figure 2. a) Number of NBT positive cells (\%) of pacu in blood collected with EDTA (clear bar) and heparin (dark bar). Results are expressed as mean \pm sd. b) Blood smear after NBT assay showing a NBT-positive cell (arrow) containing formazan precipitates.

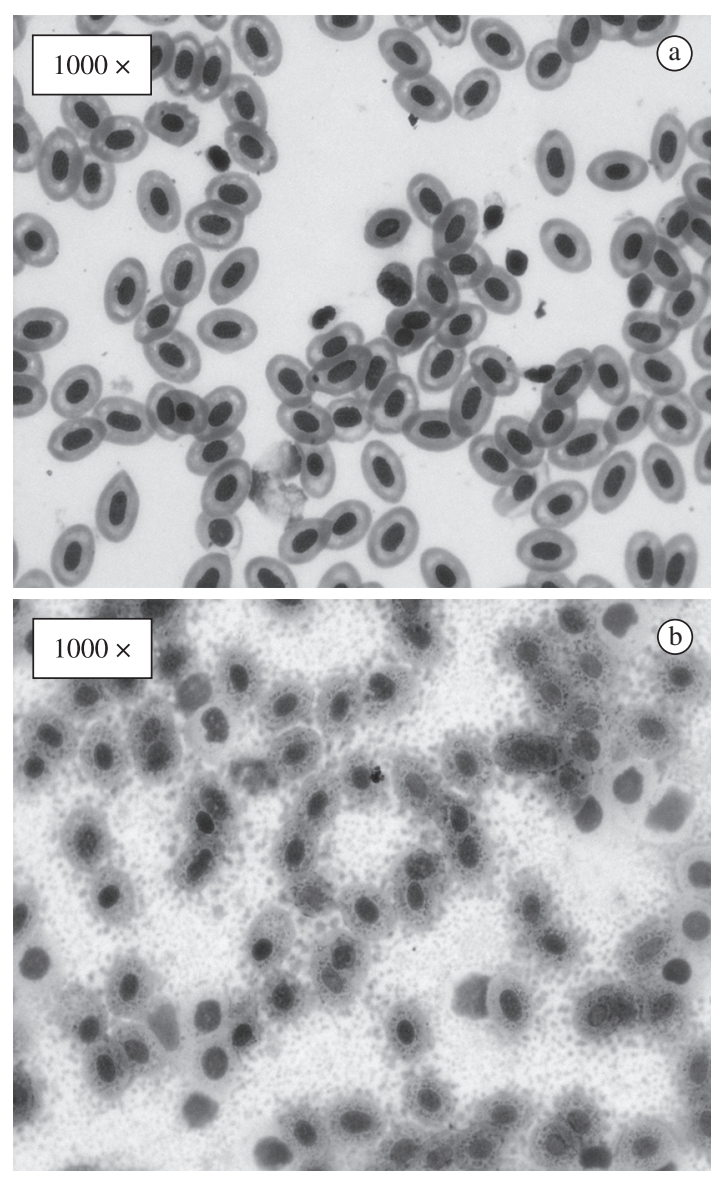
ferent volumes.

\begin{tabular}{ccc}
\hline $\begin{array}{c}\text { Volume analysed } \\
(\boldsymbol{\mu L})\end{array}$ & \multicolumn{2}{c}{ Lysozyme $\left(\boldsymbol{\mu g} . \mathbf{m L}^{-\mathbf{1}}\right)$} \\
\cline { 2 - 3 } & Serum & Plasma \\
\hline 150 & 1.14 & 0.23 \\
175 & 1.14 & 0.27 \\
200 & 1.09 & 0.36 \\
225 & 0.96 & 0.58 \\
250 & 0.89 & 0.83 \\
$\mathbf{2 7 5}$ & 0.76 & 0.91 \\
\hline
\end{tabular}

Figure 3. Blood smears of pacu with a) EDTA and b) heparin stained with Leishman's stain.

\section{Discussion}

Phagocytes are crucial in the host defense against invading microorganisms through reactive oxygen species (ROS) production. Measurement of ROS production by phagocytes is of critical importance to investigate 


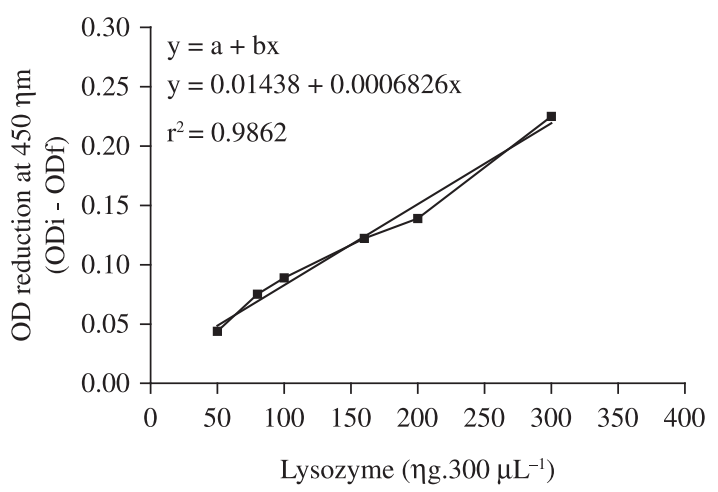

Figure 4. Calibration curve of lysozyme. Curve was obtained with lysozyme concentrations between 50 and $300 \eta$ g. $300 \mu \mathrm{L}^{-1}$. Each point represents OD reduction values for each concentration of lysozyme tested.

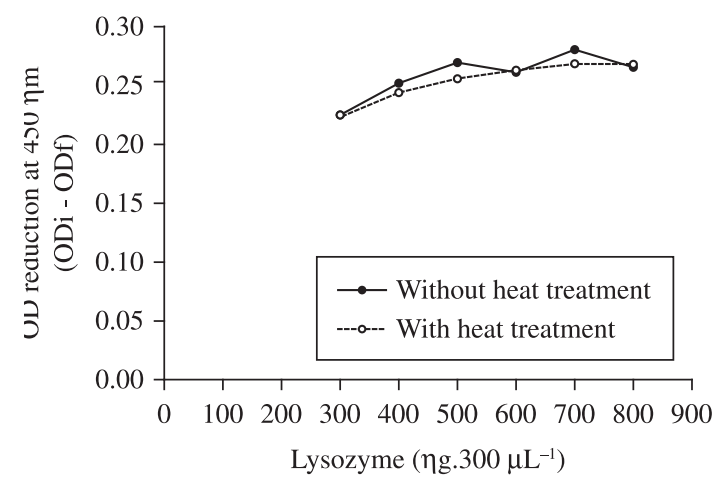

Figure 5. Calibration curve of lysozyme heated and unheated. Curve was obtained with lysozyme concentrations between 300 and $800 \eta$ g. $300 \mu \mathrm{L}^{-1}$. Each point represents OD reduction values for each concentration of lysozyme tested.

the physiological consequences resulting from cellular mechanisms that lead to the oxidative burst. In teleost fish, several methodologies can be used to measure ROS production during the respiratory burst such as chemiluminescence assay (Verlhac et al., 1996; Verlhac et al., 1998; Cuesta et al., 2002), reduction of ferricytochrome C (Jorgensen et al., 1993; Jeney et al., 1997; Santarém et al., 1997; Lee et al., 2004) and nitroblue tetrazolium (NBT) assay (Jeney and Anderson, 1993; Jeney et al., 1997; Castro et al., 1999; Cook et al., 2003; Sahoo et al., 2005). In this study, two such methodologies were selected to evaluate leukocyte burst oxidative in pacu: the chemiluminescence assay and NBT reduction assay.

Chemiluminescence is based on the amplification of natural luminescence emitted when ROS are released during phagocytosis. All the ROS convert chemiluminogenic probes, as luminol, into the aminophtalate anion, which is inherently unstable and its return to the ground state is accompanied by the release of photons. This light production is one of the characteristics of the oxidative burst (Alves et al., 2003). In this work, some difficul-

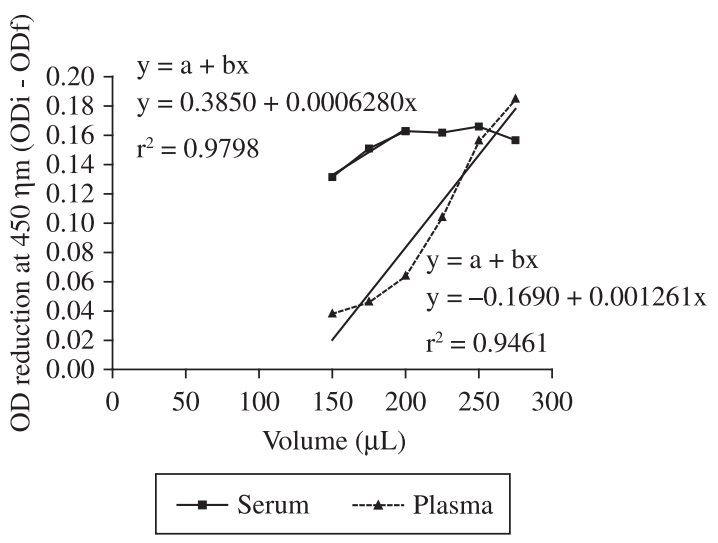

Figure 6. Inactivated serum and plasma curve of pacu with volumes between 150 e $275 \mu \mathrm{L}$. Each point represents OD reduction values for each sample volume analysed.

ties were found in the chemiluminescence assay, such as blood leucocyte isolation. In some samples it was not possible to obtain the leucocyte layer after blood centrifugation with density gradient (Histopaque ${ }^{\circledR}$ ). Figure 1 presents the chemiluminescence (CL) profile of leukocytes stimulated with PMA. In Figures $1 \mathrm{a}$ and $1 \mathrm{~b}$, the CL response observed was not satisfactory when compared to that shown in Figure 1c, which would be expected. In general, when a CL assay is carried out, the results are expressed as the area under the curve (AUC) of the chemiluminescence profile and it depends on the quality of cell suspension obtained. Unfortunately, in the present study, the isolation of leukocytes from blood was not successful. In fish, it is possible to obtain a leukocyte suspension by isolating them from head and kidney instead of blood and further studies using this tissue to isolate leukocytes should be tested in tropical fish.

The NBT reduction is a simple assay widely used to demonstrate the production of superoxide anion. The NBT accepts electrons from a variety of donor substances, such as superoxide, and thus is converted into a reduced form which precipitates as a blue-black insoluble material (formazan) on the cytoplasm of phagocytes. In this study, independent of the anticoagulant used, NBT positive cells were detected in blood smears, indicating production of oxidative radical by leukocytes. However, the leukocyte detection was more difficult on the smears of heparinized blood due to fibrinogen presence (Figure 3 ). Heparin inhibits thrombin production by preventing the conversion of fibrinogen into fibrin. Moreover, in teleost, heparin modifies leukocyte morphology and interferes in the colour of the citoplasmatic granules (Tavares-Dias and Moraes, 2004). The results presented in Figure 3 indicate that the NBT assay should be carried out with blood collected with EDTA. Moreover, NBT reduction seemed more adequate than the chemiluminescence assay. According to Jeney and Anderson (1993), the NBT assay is simple, reliable and can be available for field 
use. Since the NBT assay is easier to execute than the chemiluminescence assay, it was considered in this study, which presented the more appropriate anticoagulant (EDTA) to carry out the blood smears that are used for NBT positive cell count. However, despite the use of the NBT assay to measure leukocyte burst oxidative being intensively documented in fish, in most studies, the granules are solubilised and analysed spectrophotometrically (Castro et al., 1999; Cook et al., 2003; Sahoo et al., 2005). Only phagocytes (neutrophils, eosinophils, basophils, monocytes and macrophages) are able to accumulate formazan granules upon stimulation. Despite lymphocytes being found in fish blood circulation, they do not have some proteins of NADPH oxidase complex, whose fosforilation results in an increase in respiratory activity (Klein, 1990). For this reason, this kind of leukocyte does not accumulate formazan granules in its cytoplasm and for the NBT positive cell count, it is indispensable to identify the leucocyte population. Since the NBT assay by spectrophotometry is more accurate than NBT positive cell count, further studies using this methodology should also be carried out in tropical fish.

The serum lysozyme is used as an indicator of innate immune response in fish (Tort et al., 2003). However, there are some studies that evaluate the activity of the enzyme in plasma samples (Verlhac et al., 1996; Jeney et al., 1997; Verlhac et al., 1998). Table 1 presents the serum and plasma lysozyme levels of $P$. mesopotamicus assessed by the turbidimetric assay. With the purpose of inactivating complement system proteins and to assure that lysis of M. lysodeikticus has exclusively occurred by lysozyme action, serum and plasma samples were heated before lysozyme analysis. The heat treatment darkened the plasma samples but it did not affect the serum samples. Regarding the level of lysozyme, the serum concentration was inversely proportional (1.14 to $0.76 \mu \mathrm{g} . \mathrm{mL}^{-1}$ ) to the increase of the pipetted volume (150 to $275 \mu \mathrm{L})$, whereas the plasma concentration was directly proportional $\left(0.23\right.$ to $\left.0.91 \mu \mathrm{g} \cdot \mathrm{mL}^{-1}\right)$. Otherwise, the result in Figure 6 shows that serum lysozyme activity was higher than in plasma, suggesting that turvation observed in plasma samples interfered in lysozyme analysis since this methodology was a turbidimetric assay. Thus, the results presented in Figure 6 and Table 1 suggest that serum sample is more adequate to lysozyme analysis in pacu concerning the conditions standardised in this work.

In the inactivated serum curve (Figure 6), the volume of around $175 \mu \mathrm{L}$ promoted an OD reduction value closer than OD reduction verified in the middle of the lysozyme calibration curve (0.15), suggesting that it would be the ideal volume to be used in lysozyme analysis according to the methodology standardised for the pacu. This study established appropriate protocols to determine some innate immune responses (leukocyte respiratory burst and lysozyme level) in the tropical fish pacu. The methodologies described might be important tools to evaluate immune responses in fish in both physiological and pathological conditions and should help to develop basic research applied to fish farming in Brazil.

Acknowledgements - The authors wish to thank Prof ${ }^{\mathrm{a}}$. Dr ${ }^{\mathrm{a}}$ Yara M. Lucisano Valim and pharmacist Ana Elisa Caleiro Seixas Azzolini (Faculdade de Ciências Farmacêuticas de Ribeirão Preto, Universidade de São Paulo, Ribeirão Preto, SP, Brazil) for the support in the laboratory; Mrs. Damares Perecim Roviero (Faculdade de Ciências Agrárias e Veterinárias, Universidade Estadual Paulista, Jaboticabal, SP, Brazil) for technical assistance and the Aquaculture Centre of the State University of São Paulo (CAUNESP) for fish donation. This study was supported by a grant from $\mathrm{CNPq}$ (process number: $141143 / 2004-5)$

\section{References}

ABIMORAD, EG., CARNEIRO, DJ. and URBINATI, EC., 2007. Growth and metabolism of pacu (Piaractus mesopotamicus) juveniles fed diets containing different protein, lipid, and carbohydrate levels. Aquaculture Research, vol. 38, no. 1, p. 36-44.

ALVES, CMOS., MARZOCCHI-MACHADO, CM., CARVALHO, IF. and LUCISANO-VALIM, YM., 2003. Application of the chemiluminescence systems to evaluate the role of Fcy and complement receptors in stimulating the oxidative burst in neutrophils. Talanta, vol. 60, p. 601-608.

BALFRY, SK. and IWAMA, GK., 2004. Observations on the inherent variability of measuring lysozyme activity in coho salmon (Oncorhynchus kisutch). Comparative Biochemistry and Physiology: part B, vol. 138, no. 3, p. 207-211.

BECHARA, JA., ROUX, JP., DIAS, FJR., QUINTANA, CIF. and MEABE, CAL., 2005. The effect of dietary protein level on pond water quality and feed utilization efficiency of pacu Piaractus mesopotamicus (Holmberg, 1887). Aquaculture Research, vol. 36, no. 6, p. 546-553.

CASTRO, R., COUSO, N., OBACH, A. and LAMAS, J., 1999. Effect of different $\beta$ - glucans on the respiratory burst of turbot (Psetta maxima) and gilthead seabream (Spaurus aurata) phagocytes. Fish and Shellfish Immunology, vol. 9, no. 7, p. 529-541

COOK, MT., HAYBALL, PJ., HUTCHINSON, W., NOWAK, BF. and HAYBALL, JD., 2003. Administration of a commercial immunostimulant preparation, Eco Ativa ${ }^{\mathrm{TM}}$ as a feed supplement enhances macrophage respiratory burst and the growth rate of snapper (Pagrus auratus, Sparidae (Bloch and Schneider)) in winter. Fish and Shellfish Immunology, vol. 14, no. 4, p. 333-345.

CUESTA, A., ORTUÑO, J., RODRIGUEZ, A., ESTEBAN, MA. and MESEGUER, J., 2002. Changes in some innate defence parameters of seabream (Sparus aurata L.) induced by retinol acetate. Fish and Shellfish Immunology, vol. 13, no. 4, p. $279-291$

ELLIS, AE. Lysozyme assays. In STOLEN, JS., FLETCHER, TC., ANDERSON, DP., ROBERSON, BS. and MUISWINKEL, WB., 1990. (Ed.). Techniques in Fish Immunology. USA: SOS publications. p. 101-103.

GLASSER, L. and FIEDERLEIN, RL., 1990. The effect of various cell separation procedures on assays of neutrophil function. American Journal of Clinical Pathology, vol. 93, no. 5 , p. 662-669. 
JENEY, G. and ANDERSON, DP., 1993. Glucan injection or bath exposure given alone or in combination with a bacterin enhance the non-specific defence mechanisms in rainbow trout (Oncorhynchus mykiss). Aquaculture, vol. 116, no. 4, p. $315-329$.

JENEY, G., GALEOTTI, M., VOLPATTI, D., JENEY, Z. and ANDERSON, D., 1997. Prevention of stress in rainbow trout (Oncorhynchus mykiss) fed diets containing different doses of glucan. Aquaculture, vol. 154, no. 1, p. 1-15.

JOMORI, RK., CARNEIRO, DJ., MALHEIROS, EB. and PORTELLA, MC., 2003. Growth and survival of pacu Piaractus mesopotamicus (Holmberg, 1887) juveniles reared in ponds or at different initial larviculture periods indoors. Aquaculture, vol. 221, no. 1- 4, p. 277-287.

JORGENSEN, JB., SHARP, GJE., SECOMBES, CJ. and ROBERTSEN, B., 1993. Effect of a yeast cell wall glucan on the bactericidal activity of rainbow trout macrophages. Fish and Shellfish Immunology, vol. 3, no. 4, p. 267-277.

KLEIN, J., 1990. Immunology. Massachusetts: Blackwell Scientific Publications. p. 311-334.

KRIEGER, MHA., DELATTRE, E., CAROLSFELD, J., CECCARELLI, P. and MENEZES, FV., 1989. A time-course study of physiological indicators of handling stress in the tropical fish Piaractus mesopotamicus (pacu). Brazilian Journal of Medical and Biological Research, vol. 22, no. 8, p. 1019-1022.

LEE, SJ., KIM, SM., KIM, SK., NAM, YK., KIM, DS. and KIM, KH., 2004. Modulation of zymosan and phorbol ester stimulated respiratory burst of rock bream (Oplegnathus fasciatus) phagocytes by staurosporine, genistein and sodium orthovanadate. Aquaculture, vol. 237, no. 1-4, p. 1-7.

LIE, O., EVENSEN, O., SORENSEN, A. and FROYSADAL, E., 1989. Study of lysozyme activity in some fish species. Diseases of Aquatic Organisms, vol. 6, no. 1-5, p. 1-5.

MARTINS, ML., 1995. Effect of ascorbic acid deficiency on the growth, gill filament lesions and behaviour of pacu fry (Piaractus mesopotamicus Holmber, 1887). Brazilian Journal of Medical and Biological Research, vol. 28, no. 5, p. 563-568.

1998. Evaluation of the addition of ascorbic acid to the ration of cultived Piaractus mesopotamicus (Characidae) on the infrapopulation of Anacanthorus penilabiatus (Monogenea). Brazilian Journal of Medical and Biological Research, vol. 31, no. 5, p. 655-658.

PAULSEN, SM., LUNDE, H., ENGSTAD, RE. and ROBERTSEN, B., 2003. In vivo effects of $\beta$-glucan and LPS on regulation of lysozyme activity and mRNA expression in Atlantic salmon (Salmo salar L.). Fish and Shellfish Immunology, vol. 14 , no. 1 , p. 39-54.

ROITT, I., BROSTOFF, J. and MALE, D., 1998. Immunology. 5 ed. London: Mosby. 423 p.

ROMAGOSA, E., PAIVA, p. and GODINHO, HM., 1990. Pattern of oocyte diameter frequency distribution in females of the Pacu, Piaractus mesopotamicus (Holmberg 1887) (Colossoma mitrei Berg 1895), induced to spawn. Aquaculture, vol. 86 , no. 1 , p. 105-110.

SAHOO, PK., KUMARI, J. and MISHRA, BK., 2005. Nonspecific immune responses in juveniles of Indian major carps. Journal of Applied Ichthyology, vol. 21, no. 2, p. 151-155.

SANKARAN, K. and GURNANI, S., 1972. On the variation in the catalytic activity of lysozyme in fishes. Indian Journal of Biochemistry \& Biophysics, vol. 9, no. 2, p. 162-165.

SANTARÉM, M., NOVOA, B. and FIGUERAS, A., 1997. Effects of $\beta$ - glucans on the non-specific immune responses of turbot (Scophthalmus maximus L.). Fish and Shellfish Immunology, vol. 7, no. 6, p. 429-437.

TAKAHASHI, LS., ABREU, JS., BILLER, JD. and URBINATI, EC., 2006. Efeito do ambiente pós-transporte na recuperação dos indicadores de estresse de pacus juvenis, Piaractus mesopotamicus. Acta Scientiarum Animal Sciences, vol. 28, no. 4 , p. $469-475$.

TAVARES-DIAS, M. and MORAES, FR., 2004. Hematologia de peixes teleósteos. Ribeirão Preto: Villimpress Complexo Gráfico. 144 p.

TORT, L., BALASCH, J. C. and MACKENZIE, S., 2003. Fish immune system. A crossroads between innate and adaptive responses. Imunología, vol. 22, no. 3, p. 277-286.

URBINATI, EC. and GONÇALVES, FD., 2005. Pacu (Piaractus mesopotamicus). In BALDISSEROTTO, B. and GOMES, LC. (Ed.). Espécies nativas para piscicultura do Brasil. Santa Maria: UFSM. p. 225-255.

VERLHAC, V., GABAUDAN, J., OBACH, A., SCHÜEP, W. and HOLE, R., 1996. Influence of dietary glucan and vitamin $\mathrm{C}$ on non-specific and specific immune responses of rainbow trout (Oncorhynchus mykiss). Aquaculture, vol. 143, no. 2, p. 123-133.

VERLHAC, V. and GABAUDAN, J., 1997. The effect of vitamin $\mathrm{C}$ on fish health. Switzerland: Roche Vitamins. 30 p. (Brochura no. 51002)

VERLHAC, V., OBACH, A., GABAUDAN, J., SCHÜEP W. and HOLE, R., 1998. Immunomodulation by dietary vitamin C and glucan in rainbow trout (Oncorhynchus mykiss). Fish and Shellfish Immunology, vol. 8, no. 6, p. 409-424. 